\title{
Kant: The Sweet Dream of Perpetual Peace
}

\author{
Theodosios N. Pelegrinis \\ National and Kapodistrian University of Athens
}

\begin{abstract}
This essay is a survey upon Kant's Sweet Dream of Perpetual Peace. According to Kant, a permanent peace could be achieved under the condition of the creation of a Federation of States. This Federation of States will be rest upon three fundamental requirements-i.e., democracy, reason, universal hospitality. Kant’s idea of global Federation of States should not be confused with existing nowadays Unions of States, such as European Union, which depend heavily upon a central authority and a complicated bureaucracy.
\end{abstract}

Keywords: perpetual peace, Kant, sweet dream, global community, reason, universal hospitality, central authority, globe of common ascent, Federation of States, global village, globalization

There once was a Dutch innkeeper whose inherent satirical disposition, combined with his reasonable eagerness to advertise his inn as a tranquil place for his potential customers, led him to place a signboard above the inn's front door depicting a cemetery under a sign reading "Perpetual Peace.” This incident is being quoted by the 18th century German philosopher Immanuel Kant in his discussion of what he refers to as the "sweet dream of perpetual peace," one that philosophers have always nurtured for the future of human societies. Concerning this sweet dream, Kant argues that its fulfillment requires that societies are organized in such a way, as to have three basic features.

First of all, assumes Kant, freedom for all people should prevail, as well as isonomy and parity. These, of course, are also the fundamental requirements of democracy, which is the only regime that is based upon the consent of the citizens; if these three requirements are met, a democratic society can take the best possible decisions according to its interests. For example, as to the declaration of war, Kant argues that the citizens of a democratic state (one that decides according to the views of the majority of the people) will "think very seriously of engaging in such a wicked game, since by their consent they will be burdened with all the consequent calamities - meaning that they themselves would be the ones to fight, to fund all war expenses and to assume the entire financial burden" that a war entails. On the contrary, a totalitarian regime-where it is not the people, but some supreme lord who decides-war can be declared "almost for no reason, as if it was for a recreational feast." This is because he who decides "is hardly deprived of his banquets, hunts, palaces, court celebrations and the suchlike." Moreover, if the supreme lord wishes-for reasons of decency-to make the declaration of war seem fair or unavoidable to his subjects, "he can very well entrust this task to the diplomatic corps, which is always adequately prepared" to make out some good reasons that would justify any calamitous decision of the monarch.

In addition to these three requirements that—apart from establishing a democratic state—have also the

Theodosios N. Pelegrinis, Emeritus Professor, Department of Philosophy, National and Kapodistrian University of Athens, Greece; main research field: Philosophy (Ethics and Politics).

All references are included in Immanuel Kant’s Work Zum ewigen Frieden (1795). 
potential to make the sweet dream of perpetual peace come true, in Kant's view there is a second prerequisite of equal significance: The global community, he argues, instead of being divided into individual states, should rather assume the form of a world federation of states. The purpose of such a federation shouldn't be to "acquire any state authority, but simply to maintain and secure the freedom of each state and of other ally states without being submitted to common laws and to any other coercion on one another." In Kant's view, this is just a demand of a faculty inherent to all human beings, namely reason. "According to reason, for the states to get out of the unlawful situation —as far as their relation to each other is concerned — which results in wars, there is no other way but to create a constantly expanding state of nations, which will finally include all people on earth.” If people abided by this demand of reason, individual states would willingly coexist and collaborate, without having anymore to obey to coercive laws issued by a remote central authority.

Given that in such a world federation of states all nations are expected to coexist in harmony, Kant assumes that there is only one requirement left to be met-the third one-for his sweet dream of perpetual peace to become reality: the demand for universal hospitality. This one, in particular, stands for the "right of any foreigner not to face, at his arrival in somebody's territory, hostile reaction by the latter.” Hostility towards foreigners or persecutions are by no means justified, as long as foreigners are peaceful and behave in such ways as to cause no problems to the hosting state and its people; after all, according to Kant, the establishment of this world federation will render the globe a common asset to all its inhabitants; therefore people will be "obliged to live together one close to the other," since the planet is finite.

Nowadays, more than two centuries after Kant proved himself a fervent advocate of the establishment of a world federation of states, the entire world has become a global village; globalization is now a term familiar to everybody, and not only to philosophers or dreamers. Might it be that the time has come-due to globalization - for Kant's sweet dream to come true? In this point, it allows me to define what I mean by the term globalization: In my view, this term stands for a process that aims at establishing a confederation of states instead of individual national states, and hence to promote the collaboration between the people, to achieve faster economic growth and to maximize security and prosperity. Such a process could not be uniform; as a matter of fact, it takes various forms: It is not the same in Europe (where it is being expressed by the European Union) and in Far East. It seems that we should be much more accurate in our discussion if we referred to many globalizations rather than to an unvarying and general one. If this is true, in order to discuss what has actually become of Kant's sweet dream in today's globalized world, we should first select an individual paradigm of globalization and focus on it. In this presentation, I intend to discuss the possible affinities between the society that Kant envisioned and the one that is in our times being shaped in Europe within—and due to- - the European Union.

In my view, the strategic planning of the administrative bodies of the European Union for its state-members seems to include the establishment of an as great as possible executive authority and a substantially diminished legislative one; in this way, the approval of central policies or strategies will be subject to minimum democratic control, and therefore it will be much easier. There are so far some key-policies proposed by the central administrative bodies of the European Union Administration that have been rejected by member-states either due to general public disapproval that has been expressed through referenda, or by intense parliamentary reaction.

This tendency, of course, causes an ever growing shortfall of democracy in national states, which is being felt not only by the citizens of each individual state, but also by people who have sought shelter in the European 
Union in their effort to escape unbearable conditions in their countries, mainly extreme poverty and persecutions. Immigrants still in many cases are being treated as outcasts in some member states of the European Union, and the more so as long as they represent a threat to the economy of each individual state. The situation for these people in our times has become much more difficult than it has been in the past, since the authorities due to the technological advances in the field of security are facilitated with much more efficient methods of control: not long ago, the governments of Malta and Italy rushed to declare the Mediterranean a graveyard for any immigrant; time and again, the people have the opportunity to watch speechless through their screens (sometimes hundreds of) immigrants drowning or being shot while trying to enter European terrain in the pursuit of a better life.

Within such a paradigm as the European Union, but also in any other contemporary expression of globalization, nobody would be justified to believe that Kant's sweet dream for perpetual peace and prosperity; the final purpose for humans, has already become reality, or is about to. None of the three prerequisites Kant thinks necessary for the achievement of perpetual peace and prosperity seems to have been met due to globalization, at least the way it has so far developed: The three demands of democracy remain not fully satisfied; no decentralized world federation of states has yet been established; and surely the principle of generalized hospitality has not yet prevailed.

This, of course, is not the first time that Kant's dream proves false during the centuries that followed his death. Moreover, one might be justified to fear that there are going to be many more failures, unless those that have the power to draw the lines for a world community of nations take seriously into consideration Kant's recommendation: to avoid creating a federation of states governed by a central authority that will fully control member states by coercive laws and detailed instructions, and, instead, to invest all their efforts in persuading the citizens of each member state to seek in themselves the power of reason. Reason is the only human property that can control the "malignancy of our nature," which is the source of the competition among us and of all human suffering. If this happens, the time will come when people will finally manage to act in accordance with a demand of reason that is of the most pivotal significance for the realization of the sweet dream of perpetual peace: to treat others always as an end and never solely as a means. 